\title{
Commentary: Postoperative blood transplantation for non-small cell lung cancer
}

\author{
Kelli D. Salter, MD, PhD, and Bryan M. Burt, MD
}

\author{
From the Division of General Thoracic Surgery, Michael E. DeBakey Department of Surgery, Baylor College of \\ Medicine, Houston, Tex. \\ Disclosures: Authors have nothing to disclose with regard to commercial support. \\ Received for publication Jan 15, 2019; accepted for publication Jan 16, 2019; available ahead of print March 4, \\ 2019. \\ Address for reprints: Bryan M. Burt, MD, Division of General Thoracic Surgery, Department of Surgery, Baylor \\ College of Medicine Michael E. DeBakey, One Baylor Plaza, MS BCM 390 Houston, TX 77030 (E-mail: \\ bryan.burt@bcm.edu). \\ J Thorac Cardiovasc Surg 2019;157:2480-1 \\ $0022-5223 / \$ 36.00$ \\ Copyright (c) 2019 by The American Association for Thoracic Surgery \\ https://doi.org/10.1016/j.jtcvs.2019.01.049
}

Debate on appropriate triggers for transfusion of allogeneic blood products and their effects on short-term and longterm survival in patients with cancer continues with no definitive evidence or decisive resolution. Although mechanisms of transfusion-related immunomodulation have been proposed, ${ }^{1}$ its influence on immune competence in the recipient and its effect on cancer recurrence after curative resection remain controversial. Association between perioperative transfusion of allogeneic blood products and elevated risk of recurrence and reduced survival has been shown in other cancer types, including colorectal, hepatocellular, prostate, breast, melanoma, and pancreatic, ${ }^{2-4}$ but the effects in patients with lung cancer remain indeterminate. Previous investigations examining the relationship between blood transfusion and lung cancer recurrence and survival resulted in no definitive conclusions; however, a statistical trend supported the theory that blood transfusion in patients undergoing resection for lung cancer was associated with poorer outcomes. $^{5-7}$

In this issue of the Journal, Latif and colleagues ${ }^{8}$ investigate a dose-dependent effect of perioperative blood transfusion on the overall survival and disease-free survival in patients undergoing anatomic lung resection for nonsmall cell lung cancer. A dose-dependent detrimental effect was observed with a multivariable Cox proportional hazards analysis in patients receiving 2 or more units of blood: cumulative worse overall survival $(P<.001)$, disease-free survival $(P<.001)$, and recurrence $(P=.010)$. Patients receiving 8 or more units of blood were most negatively affected with hazard ratios for overall survival, diseasefree survival, and cumulative risk of recurrence of 4.29 , 3.57 , and 1.58 , respectively.

The role of the host immune system in the outcomes of non-small cell lung cancer has never been more obvious than in recent years. ${ }^{9,10}$ Immune evasion by cancer occurs through complex interactions among tumor cells, surgeons.

\section{References} 336-40. Metastasis. 2016;9:1-8.

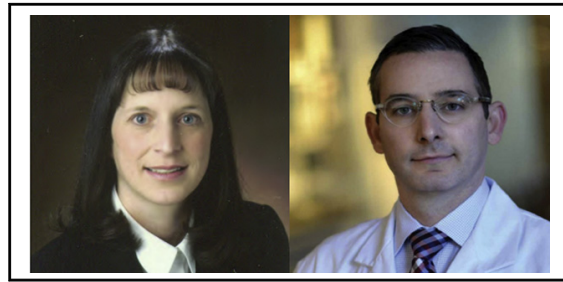

Kelli D. Salter, MD, PhD, and Bryan M. Burt, MD, Baylor College of Medicine.

Central Message

Transplantation of allogeneic blood products results in unfavorable oncologic outcomes for patients with non-small cell lung cancer.

See Article page 2469.

immune cells, and the microenvironment that are almost certainly influenced by blood transfusion. Components of transfused allogeneic blood products including cytokines and major histocompatibility complex molecules on residual leukocytes are thought to stimulate immune responses not dissimilar to those against transplanted solid organs. It is hypothesized that the resultant transfusion-related immunomodulation can potentially subvert or dampen effective antitumor immunity ${ }^{1-4}$ and enable tumor progression; however, substantial gaps remain in understanding these mechanisms. Nonetheless, this study demonstrates the unfavorable clinical impact of blood transfusion in patients with operative lung cancer that should be eye-opening to practicing thoracic

1. Kirkley SA. Proposed mechanisms of transfusion-induced immunomodulation. Clin Diagn Lab Immunol. 1999;6:652-7.

2. Goubran H, Sheridan D, Radosevic J, Burnouf T, Seghatchian J. Transfusion-related immunomodulation and cancer. Transfus Aphar Sci. 2017;56:

3. Goubran HA, Elemary M, Radosevich M, Seghatchian J, El-Ekiaby M, Burnouf T. Impact of transfusion on cancer growth and outcome. Cancer Growth

4. Cata JP, Wang H, Gottumukkala V, Reuben J, Sessler DI. Inflammatory response, immunosuppression, and cancer recurrence after perioperative blood transfusions. Br J Anaesth. 2013;110:690-701.

5. Cata JP, Chukka V, Wang H, Feng L, Gottumukkala V, Martinez F, et al. Perioperative blood transfusions and survival in patients with non-small cell lung cancer: a retrospective study. BMC Anesthesiol. 2013;13:42.

6. Wang T, Luo L, Huang H, Yu J, Pan C, Cai X, et al. Perioperative blood transfusion is associated with worse clinical outcomes in resected lung cancer. Ann Thorac Surg. 2014;97:1827-37. 
7. Cata JP, Gutierrez C, Mehran RJ, Rice D, Nates J, Feng L, et al. Preoperative anemia, blood transfusion, and neutrophil-to-lymphocyte ratio in patients with stage I non-small cell lung cancer. Cancer Cell Microenviron. 2016;3:e1116.

8. Latif MJ, Tan KS, Molena D, Huang J, Bott MJ, Park BJ, et al. Perioperative blood transfusion has a dose-dependent relationship with disease recurrence and survival in patients with non-small cell lung cancer. $J$ Thorac Cardiovasc Surg. 2019;157:2469-77.e10.
9. Gandhi L, Rodriquez-Abreu D, Gadgeel S, Esteban E, Felip E, De Angelis F, et al. Pebrolizumab plus chemotherapy in metastatic non-small-cell lung cancer N Engl J Med. 2018;378:2078-92.

10. Hellmann MD, Ciuleanu TE, Pluzanski A, Lee JS, Otterson GA, AudigierValette C, et al. Nivolumab plus ipilimumab in lung cancer with a high tumor mutational burden. N Engl J Med. 2018;378:2093-104. 